\title{
INTERNAL AUDITING IN COVID-19 ENVIRONMENT: IS REMOTE AUDITING A SOLUTION?
}

\author{
Vule Mizdrakovicí, \\ Maja Kljajić', \\ Blaženka Hadrović Zekić ${ }^{3}$
}

\author{
${ }^{1}$ Singidunum University, \\ Belgrade, Serbia \\ ${ }^{2} \mathrm{PhD}$ candidate, \\ Singidunum University, \\ Belgrade, Serbia \\ ${ }^{3}$ Faculty of Economics in Osijek, \\ Osijek, Croatia
}

\begin{abstract}
:
The global pandemic caused by the new coronavirus COVID-19 disease flared up around the world and it was very difficult to predict. When it comes to the worldwide economy, there is no doubt that the pandemic will have serious consequences because, besides being a health crisis, pandemic has already turned into a great economic and financial crisis. This, in turn, left the management of service providing entities left with a dilemma -to choose the right model for their business activities and care for their employee's health at the same time. This paper discusses possible solutions related to internal audit, as a service providing profession. It also analyses advantages and disadvantages of internal auditing activities performed before and during the pandemic. The authors' findings lead to the conclusion that auditors could use this business environment as an opportunity for complete digital transformation since the function of internal audit can be further improved using new information and communication technologies.
\end{abstract}

\section{Keywords:}

remote auditing, pandemic, internal auditor, digital transformation, ICT.
Correspondence:

Vule Mizdraković

e-mail:

vmizdrakovic@singidunum.ac.rs

\section{INTRODUCTION}

Daily changes in modern business environment are some of the main characteristic and they have an effect on the labour market, as well. The emergence of a global pandemic caused by the COVID-19 brought with it additional uncertainty, risks and challenges to an already fast-paced environment and changed current business conditions. This, in turn, forced many countries around the world to restrict and at one moment, even ban office work. For example, the Government of the Republic of Serbia passed the Decree on Organization of Work by Employers during the State of Emergency (Official Gazette of RS, 31/20, 2020). The decree prescribed that work should be organized from home, that business hours should be harmonized and that, when it is not possible, working from home should be organized while the state of emergency lasted. Generally speaking, all industries have been affected by the global pandemic, and will continue to feel financial consequences of it even after it ends. For example, the impact on the Gross Domestic Product in the Republic of Serbia can already be noticed, if we compared the figures from 2019 (GDP rate: +4.2 ) and 2020 (GDP rate: -1.0) [ CITATION The201 \19242 ]. To prevent additional losses, business entities should adapt to their current business environment and increase their operational capacity. Workforce is one of those key elements in such situations because their innovative ways of thinking and willingness to use modern information and communication technology (ICT) to a larger extent, will be reflected on the adoptability of whole business entities (Stanisic, Spahic, \& Tomin, 2018). 
Internal audit is focused on the comprehensive operations of the entity, where constant control of business activities is carried out, such as: monitoring, verification and improvement of performing activities; identification of the risks to which the entity is or may be exposed; assessment and evaluation of internal controls; and providing appropriate recommendations to address deficiencies and noticed irregularities (Rew - Est d.o.o., 2018). This paper will discuss how internal auditors should respond to the current business environment and at the same time provide the same or higher level quality of their services.

\section{EFFECTS OF COVID-19 PANDEMIC ON INTERNAL AUDITING}

The need for reliable information for business, strategic and other decision-making process is a vital need of an entity. In that sense, the role of the internal auditor is of great importance, bearing in mind that his/her results can be used to meet the information needs of stakeholders within the company, primarily entity owners and different levels of management, but also the supervisory, executive and audit boards. According to International Standard on Auditing 610, the external auditor refers to the work of internal auditors, which indicates that the external audit is one of the users of internal audit services. The main difference between internal and external audit is that the latter function is outsourced, namely external auditor will be hired by a business entity to perform their audits. However, internal audit as a function of an entity should be part of it, and internal auditor should be employed to perform its activities for the needs of the supreme governing body in the company. However, modern business conditions and the possibility of achieving maximum efficiency and effectiveness in the market have imposed the need to entrust internal audit to business entities that perform internal audit services as their main business activity (so-called internal audit outsourcing). In that case, the internal auditor will not be permanently employed within the entity but will be hired on a contract basis. This was an important factor in adapting to the current business environment, as outsourced internal auditors were probably already using ICT in their work, trying to minimise the need to be physically present on the company's premises.

Even before the global pandemic, the accounting and auditing profession faced the need to revise the strategy and methodology they use to perform activities, as well as introduce a complex process of digitization and digital transformation; in order to improve its function. Digital transformation and other new technologies changed many internal audit functions until the outbreak of the pandemic (Serag \& Daoud, 2021).
The author (Tusek B., 2019) states that the accelerated application of digital technology brings numerous and fundamental changes in business models, strategies, organizational structure, business processes and their adaptation to the digital age. As no process takes place overnight, adaptation to the new circumstances and conditions has lagged behind, both due to limited resources and resistance of employees to change. However, the pandemic has confronted auditors with a suddenly new approach to work and accelerated digitization in performing activities. Therefore, they are facing new unexpected and unknown inherent risks that they have to deal with in performing auditing engagements (Tusek, Ježovita, \& Halar, 2020).

Additionally, standard setters and regulatory bodies reacted to the changes in business environment by revising issued standards and additionally providing guidelines for auditors and accountants. Namely, there is a significant impact on the activities of accountants and auditors in preparing financial statements in accordance with International Financial Reporting Standards (IFRS), as well as their audit, in accordance with International Standards on Auditing (ISA). In March 2020, the International Auditing and Assurance Standards Board (IAASB) issued the first statement on the work during the global pandemic, sampled by COVID-19. The Board states that the audit, whether internal or external, should be performed in accordance with the required standards. The Board also states that auditors may need to consider developing alternative procedures to gather sufficient and appropriate audit evidence to support their audit opinion or to amend the audit opinion (IAASB, 2020). Areas that the IAASB considers particularly important in this regard are auditor reporting; going concern; subsequent events; auditing accounting estimates; considerations for public sector audit considerations. By September 2021, a total of 17 communications in the form of accounting and auditing guidelines were issued at the time of COVID-19, which could indicate changes needed to be done (IAASB, 2020). The Institute of Internal Auditors states some of those changes that chief internal auditors could expect during a pandemic in terms of the way the internal audit process is conducted (Audit Executive Center, 2020):

- increased use of data analysis procedures (Data Analytics);

- increased use of agile audit techniques (Agile Auditing Techniques);

- providing advisory engagements;

- identifying ways to save costs (Cost Management);

- reducing the time needed to complete internal audit engagement;

- increasing the use of audit software packages and ICT; 
- investing in automation of the internal audit process; and

- increasing the use of robotic process automation.

Also, the IAASB conducted a survey on a sample of 486 chief internal auditors and internal audit officers from the United States and Canada during 2020. Regulating body investigated perceptions of the long-term effects of the COVID-19 pandemic on the efficiency and effectiveness of internal audit functions. The results of the research showed that the key areas of action of internal auditors, on which the COVID-19 pandemic will have long-term effects, are: budgets of internal audit functions, frequency of risk assessment and updating of internal audit plans with the audit committee, and increasing demand for certain competencies and skills (IAASB, 2020).

\section{THE ROLE AND SIGNIFICANCE OF REMOTE AUDITING CONCEPT}

In times of crisis, the function of internal audit is crucial in the process of risk management and control, because the auditor can give relevant advice and assessments that correspond to the organizational structure of the observed entity. Therefore, internal auditors should be part of crisis management teams in companies, to ensure adequate response to all challenges and provide advisory support to management. Internal auditors are expected to pay special attention to employees, processes and technology when conducting a pandemic impact analysis on the company's operations (Audit Board, 2020). They are also expected to work on related internal controls to minimize these risks (Pempal IACOP, 2020). Although most companies have Disaster Recovery and Business Continuity Plans in place, it was impossible to predict a crisis-like situation caused by the current global pandemic. Namely, business entities lacked key resources, employees, who had to switch to online work (Audit Board, 2020), (KPMG, 2020), (Teeter, Alles, \& Vasarhelyi, 2010).

As it has been mentioned, auditing profession faced unexpected challenges as, during the COVID-19 pandemic, internal and external auditors had to switch to different methodology in order to perform their activities. In this way, traditional audit has been replaced by remote audit, which requires modification of the audit methodology and application of advanced data analysis techniques. Internal auditors are faced with increased requirements for consulting engagements, as well as significant changes in business processes that result in previously non-existent risks. Thus, remote audit results in the need for updating and significant changes in strategic, annual and individual plans (Tusek, Jezovita, \& Halar, 2020).
Remote audit, also known as virtual audit, is a method of conducting an audit, using modern technology to obtain audit evidence. Authors (Teeter, Alles, \& Vasarhelyi, 2010) define remote audit as "the process by which internal auditors link information and communication technologies with data analytics to collect and evaluate electronic evidence, interact with the auditee and report on the accuracy of financial data and internal controls, independently from the auditor's physical location ". Unlike traditional, remote audit is performed partially or completely off-site. In this regard, two main approaches can be distinguished for conducting a remote audit, namely: partial remote audit and full remote audit.

Partial remote audit is a combination of remote procedures and on-site procedures. Remote procedures will follow the standard part of the audit using technological tools to access the necessary evidence and collect a limited number of surveys or interviews from employees or third parties, as well as other visual evidence. The on-site procedures aim to verify the conclusions gathered from the remote procedures and to conduct additional tests of issues that could not be verified through the remote audit process. On the other hand, a full remote audit is performed using modern information technologies for gathering evidence. A full remote audit should follow a standard audit flow using technological instruments and tools to access the necessary evidence, including interviews, using appropriate sampling techniques (Serag \& Daoud, 2021).

\section{ADVANTAGES AND DISADVANTAGES OF REMOTE AUDITING}

The way of doing business ex-ante COVID-19 pandemic, in most cases, required personal visits of remote areas in order to collect the necessary data. Therefore, the auditor had to make additional efforts to reach a particular auditee and perform the necessary tasks. Significant travel-related efforts and costs are the primary reason why remote audit (without personal presence) has become attractive to internal, as well as external auditors (Christ, Eulerich, Krane, \& Wood, 2021). Commonly mentioned advantages of remote auditing are reflected in the following: time and money savings by using ICT, avoiding personal visits of remote areas, increasing the scope of audit, increased efficiency of the audit team, double-checking documents leads to more relevant evidence, increased use of ICT strengthens documentation and reporting, logistics related to auditing is not needed anymore (Serag \& Daoud, 2021).

When it comes to the literature from this field, there has been some research done on the topic and the following text will provide a brief review. 
Authors (Eulerich, Wagener, \& Wood, 2021) in their research presented the results of a survey conducted during 2020, which involved 271 German internal auditors that conducted remote and traditional audits. Based on their responses, the research showed that internal auditors did not notice any differences in the efficiency and effectiveness of stakeholders' trust in the results of remote and traditional audits. Also, research showed that there is a positive correlation between the perception of efficiency and effectiveness and internal auditor's experience with remote audits. Namely, the perception of efficiency and effectiveness increased as the internal auditor's experience with remote audits increased. Additional analyses showed that expected success of a remote audit predominantly depends on the auditee support.

From the standpoint of the impact of remote audit on the level of quality of provided internal audit services, the authors have conflicting opinions. The first group of authors conclude in their work that the quality of audit will be reduced (Bennett \& Hatfield, 2018), (Saiewitz, 2018) and (Saiewitz \& Kida, 2018). The mentioned authors noticed in their works that personal interactions are important for the quality of the audit. Namely, when auditors personally visit an auditee, they can get better conclusions through non-verbal communication, or they are able to obtain more answers, compared to interactions via e-mail. Therefore, audit clients and third parties believe that auditors' personal requests are more urgent and important than e-mail requests. In addition, they expect a higher number of questions in face-to-face interactions.

On the other hand, the authors (Carlisle, 2018) and (Hawkins, 2017) suggest that remote auditing would in fact improve audit quality. The first author claims that an auditor will be more neutral in remote auditing as he/she will not be influenced by auditee management and will try to find their own source of information to confirm the claims given in financial reporting. The second author claims that when auditors are not physically present at an auditee's premises, he/she will show higher level of scepticism, compared to traditional audit when an auditor may place too much reliance on auditee management presentations.

\section{CONCLUSION}

The spread of the pandemic caused by COVID-19 has imposed new business conditions around the world. While countries struggled to adopt timely measures to combat it, business entities still had to make important decisions that would help them keep their businesses afloat. The global economic and financial consequences are likely to be felt in all industries and activities, even after the end of the pandemic. The above led company managements to lay particular emphasis on their employees during the pandemic, by introducing special protection measures in the form of remote work, amid efforts to suppress the spread of this type of coronavirus. It can be concluded that internal auditors should use current COVID-19 environment as an opportunity to improve their effectiveness and efficiency by resorting to digital transformation. The authors from this field mention different advantages of using remote auditing concept, with cost savings being the most important ones. Furthermore, an auditor may appear more neutral compared to traditional audit as he/she will express higher levels of scepticism towards the auditee. If we go back to the research question defined in the title of this paper, we can conclude that remote auditing is definitely a proper solution in the COVID-19 environment, but it can also be used in regular conditions in its partial form. Finally, it can be concluded that remote auditing could possibly result lead to resorting to smarter ways to perform internal auditing in the future, which may have a positive effect on employees' willingness to adapt to new business environment. 


\section{LITERATURE}

Audit Board. (2020). Internal Audit. Retrieved from COVID-19 Response Strategy: Evolving Internal Audit Practices for Success: https://www.auditboard.com/blog/covid-19-response-strategy-internal-audit-practices/

Audit executive center. (2020). COVID-19: Longer term impact on Internal Audit. Retrieved from https://dl.theiia. org/Documents/COVID-19-Longer-Term-Impact-onInternal-Audit.pdf

Bennett, G., \& Hatfield, R. (2018). Staff auditors' proclivity for computer-mediated communication with clients and its effect on skeptical behavior. Accounting, Organizations and Society, 68(1), 42-57.

Carlisle, M. (2018). Auditors' evaluation of evidence: The effect of communication channel and management competence information.Working paper Case Western Reserve University.

Christ, M., Eulerich, M., Krane, R., \& Wood, D. (2021). New frontiers for internal audit research. Working Paper, University of Georgia, University of Duisburg-Essen.

Eulerich, M., Wagener, M., \& Wood, D. (2021). Evidence on Internal Audit Effectiveness from Transitioning to Remote Audits because of COVID-19. Retrieved from file://Users/apple/Downloads/EWWSSRN.pdf

Hawkins, E. (2017). When auditors' skeptical judgments do not lead to skeptical actions. Working paper; Clemson University.

IAASB. (2020). Staff Audit Practice Alert. Retrieved from Highlighting areas of focus in an evolving audit environment due to the impact of COVID-19: https://www. iaasb.org/publications/highlighting-areas-focus-evolving-audit-environment-due-impact-covid-19-1

KPMG. (2020). Coronavirus and the role of internal audit leaders. Retrieved from https://home.kpmg/ch/en/blogs/ home/posts/2020/03/coronavirus-role-of-internal-audit. html

Official Gazette of RS, 31/20. (2020). Legal information system of the Republic of Serbia. Retrieved from Decree on organizing the work of employers during a state of emergency 31/2020-3: https://www.pravno-informacioni-sistem.rs/SlGlasnikPortal/eli/rep/sgrs/vlada/ure$\mathrm{dba} / 2020 / 31 / 2 /$ reg

Pempal IACOP. (2020). The impact of COVID-19 on the role and activities of internal audit. Retrieved from https:// www.pempal.org/sites/pempal/files/IACOP/covid_publication_pages_.pdf

Rew - Est d.o.o. (2018). Retrieved from Eksterna i interna revizija: https://revizor.ba/blog/eksterna-i-interna-revizija/

Saiewitz, A. (2018). Email versus in-person audit inquiry: Recent research and additional survey data. Current Issues in Auditing, 12(2), 36-44.
Saiewitz, A., \& Kida, T. (2018). The effects of an auditor's communication mode and professional tone on client responses to audit inquiries. Accounting, Organizations and Society, 65(1), 33-43.

Serag, A., \& Daoud, M. (2021). Remote Auditing : An Alternative Approach to Face the Internal Audit Challenges During The COVID-19 Pandemic. Atasu Journals, 228259.

Stanisic, M., Spahic, N., \& Tomin, M. (2018). Revizija aplikativnih kontrola. Sinteza - International scientific conference on information technology and data related research, (p. 343).

Teeter, R., Alles, M., \& Vasarhelyi, M. (2010). The remote audit. Journal of Emerging Technologies in Accounting, 7(1), 73-88.

The Serbian Business Registers Agency (SBRA). (2020). Publications. Retrieved from Macroeconomic analysis:https:// www.apr.gov.rs/registers/financial-statements/ publications/\%D0\%BCacroeconomic-analysis.1805. html

Tusek, B., Jezovita, A., \& Halar, P. (2020). Izazovi djelovanja interne i eksterne revizije u eri pandemije COVID-19. Zbornik radova - Journal of Economy and Business, 26(1), 111-130.

Tusek, B. (2019). Utjecaj digitalizacije na internu reviziju. Računovodstvo, revizija i porezi u susret digitalizaciji i eurozoni, 73-92. 